http://journal.uin-alauddin.ac.id/index.php/lamaisyir

Publisher: Fakultas Ekonomi dan Bisnis Islam UIN Alauddin Makassar

\title{
Islamic Social Finance Optimalization For Economic Growth (Covid 19 In Indonesia)
}

\author{
Inggritia Safitri M${ }^{1}$, Nurul Huda ${ }^{2}$ \\ 1,2Universitas Indonesia \\ 1,2 Gedung Sekolah Kajian Stratejik dan Global, Jl.Salemba Raya 4 Jakarta \\ inggritiasafitri@gmail.com ${ }^{1}$, pakhuda@yahoo.com ${ }^{2}$
}

Received: 17 October 2020; Revised: 20 Desember 2020; Published: 23 Februari 2021

\begin{abstract}
ABSTRAK
Dampak Covid 19 berpengaruh besar bagi lembaga keuangan, hingga masyarakat menengah kebawah di Indonesia. Penelitian ini bertujuan untuk mengoptimalisasikan ISF untuk meningkatkan pertumbuhan ekonomi ditengah pandemi. Penelitian ini menggunakan pendekatan kualitatif deskriptif dan teknik riset kepustakaan. Zakat dengan cepat dapat dilakukan pengumpulan dana untuk program bantuan pangan, kesehatan, dan program konsumtif lainnya, sehingga zakat dapat mengatasi krisis pangan pandemi Covid 19. Sedangkan jangka panjang zakat dioptimalkan dalam program pendidikan dan ekonomi. Infaq dan sedekah dapat diperoleh langsung secara tunai dari unit pengumpul zakat dan masyarakat. Instrumen wakaf lebih diperuntukkan dalam periode jangka panjang, terutama wakaf uang dalam bentuk Cash Waqf Linked Sukuk menarik wakif untuk berwakaf dan berinvestasi mengembangkan infrastruktur. Penelitian menyimpulkan ISF menjadi solusi dalam meningkatkan pertumbuhan ekonomi ditengah pandemi Covid 19 dengan memplotkan instrumen tersebut dalam jangka pendek, dan panjang. Sehingga masyarakat teratasi secara optimal, dan perekonomian dapat bertahan dan mengalami pertumbuhan kembali secara normal.
\end{abstract}

\section{Kata kunci: Covid 19; CWLS; Pertumbuhan Ekonomi}

\section{ABSTRACK}

Covid 19 has had a significant impact on financial institutions and the middle and lower classes in Indonesia. This study aims to optimize the ISF to increase economic growth amid the pandemic. This study uses a descriptive qualitative approach and library research techniques. Zakat can quickly raise funds for food aid programs, health, and other consumptive programs so that zakat can overcome the Covid 19 pandemic food crisis. Meanwhile, in the long term, zakat is optimized in education and economic programs. Infaq and alms can be obtained directly in cash from the zakat collection unit and the community. Waqf instruments are more intended for long-term periods, especially cash waqf in Cash Waqf Linked Sukuk to attract waqf for waqf and invest in developing infrastructure. The research concludes that ISF is a solution in increasing economic growth amid the Covid 19 pandemic by plotting these instruments in the short and long term. So that society can be resolved optimally, and the economy can survive and experience average growth again.

Keywords: Covid 19; CWLS; Economic Growth 


\section{PENDAHULUAN}

Dunia Islam saat ini memiliki kecenderungan penguatan dan memanfaatkan dana sosial yang telah dimiliki instrumen keuangan syariah, dalam hal ini yaitu keuangan sosial syariah atau Islamic Social Finance. Islamic Social Finance/ISF ini juga sudah menjadi isu yang menarik diberbagai negara Islam, terutama negara yang termasuk dalam Organisasi Kerjasama Islam/OKI yang sudah menyadari besarnya potensi Islamic Social Finance ini. Berbicara tentang Islamic Social Finance, instrumen yang selalu digunakan oleh masyarakat muslim adalah zakat, Wakaf, infak, dan sedekah. Menurut Rohim, Tanjung, and Beik (2018) potensi tinggi dari ISF sangat berhubungan erat dengan asumsi pengentasan kemiskinan. Instrumen zakat dapat kita ambil sebagai contoh. Secara logika masyarakat akan berasumsi semakin besar potensi zakat maka semakin besar peluang pengentasan kemiskinan. Namun permasalahan selanjutnya adalah potensi zakat yang besar belum dapat dilaksanakan secara maksimal, walaupun sudah berjalan dengan baik.

Sebelum berlanjut membahas kemiskinan hingga kondisi perekonomian nasional, dunia saat ini sedang dihadapi oleh pandemi Covid 19 yang memicu krisis ekonomi nasional hingga krisis ekonomi secara global. Menurut WHO Covid 19 ditemukan pertama kali di Wuhan, China pada Bulan Desember 2019. Virus tersebut menyebar hingga setiap negara di belahan dunia. Pada Bulan Mei, 2020 virus ini menginfeksi setidaknya 3.175 .207 orang dengan kematian sebanyak 224.172 orang secara global. Sementara di Indonesia, Covid 19 sudah ada pada Bulan Maret 2020 dengan dua kasus pertama yang dikonfirmasi berada di Kota Depok, Jawa Barat. Menurut Departemen Kesehatan per Mei 2020, terdapat 10.551 kasus yang dikonfirmasi sebanyak 800 orang meninggal dunia dan sebanyak 1.591 pasien telah pulih dari Covid 19. Berdasarkan data tersebut, Indonesia memiliki tingkat kematian $7,58 \%$ sehingga menjadikan Indonesia sebagai salah satu negara yang paling tinggi terkena Covid 19 di dunia.

Pandemi Covid 19 ini hampir dirasakan oleh seluruh lembaga keuangan termasuk Lembaga keuangan Syariah, UMKM hampir disemua sektor hingga masyarakat menengah kebawah yang kesehariannya mendapat penghasilan yang tidak tetap seperti pedagang kaki lima yang rentan terhadap Covid 19. Setidaknya di pasar keuangan, terdapat dua indikator utama yang terkena dampak ini. Pertama, nilai tukar Rupiah mencapai 16.575 rupiah per tanggal 23 Maret 2020. Nilai tukar tersebut menjadi nilai terlemah sejak krisis keuangan tahun 1998. 
Kedua, adalah Indeks Harga Saham Gabungan yang mengalami penurunan. Harga saham mencapai Rp 6.200 pada Bulan Januari 2020 mengalami penurunan besar mencapai Rp 4.000 pada Bulan Maret sebelum rebound menjadi Rp 4.500 pada awal April berkat adanya sentimen positif dari perusahaan farmasi seperti Sidomuncul, Indo Farma, Kimia Farma, dan Kalbe Farma karena meningkatkan permintaan terhadap produk yang dihasilkan perusahaan yang bersangkutan.

Selain dua indikator diatas, menurut Sukmana, Indrawan, and Ajija (2020) lembaga keuangan syariah seperti perbankan syariah diprediksi akan menghadapi NPF yang tinggi karena nasabah perbankan syariah memiliki kendala keterlambatan pembayaran, atau pembatalan proyek konstruksi yang telah disepakati sebelumnya oleh perbankan syariah. Sementara di pasar modal syariah, dikhawatirkan banyak investor asing yang akan melakukan penarikan dana yang akan membahayakan pasar modal syariah dan pasar valuta asing.

Sektor UMKM merupakan salah satu katalisator ekonomi di Indonesia bagi resesi ekonomi Indonesia (Mussry, Ridwansyah, Meiza, \& Laksmana, 2020). Berdasarkan riset yang dilakukan oleh International Council for Small Business tahun 2020, dari segi aspek pemasaran sektor UMKM mengalami penurunan pemrintaan pelanggan sebesar $78,2 \%$ dan kesulitan berjualan secara daring sebesar $17 \%$. Sedangkan dari aspek operasional, terjadi kenaikan harga bahan baku sebesar 51,8\% dan kesulitan mendapatkan bahan baku sebesar 32,9\%. Aspek sumber daya manusia juga memiliki penurunan motivasi kerja sebesar $53,3 \%$ serta penurunan produktivitas sebesar $29,7 \%$. Sedangkan aspek finansial, sektor UMKM mengahadapi kekurangan kas sebesar 58,2\%.

Kondisi perekonomian Indonesia saat ini sudah menghadapi krisis ekonomi. Jika dikaitkan dari perspektif makroekonomi, Bank Indonesia memprediksi bahwa pertumbuhan ekonomi tahun ini berada pada kisaran 4,2\%4,6\% lebih rendah dari tahun 2019 sebesar 5,02\%. Pemulihan diperkirakan akan dilakukan pada tahun 2021 yaitu pada kisaran 5,2\%-5,6\%. Hal demikian akhirnya membuat pemerintah melakukan stimulus baik dari kebijakan fiskal maupun moneter.

Kebijakan moneter yang yang dilakukan oleh Bank Indonesia salah satunya adalah menurunkan tingkat suku bunga acuan Bank Indonesia mencapai angka 4,5\%. Selain itu Bank Indonesia tetap akan melakukan dan meningkatkan intensitas triple intervention dan mengoptimalkan operasi moneter untuk menjaga likuiditas. Sedangkan dari kebijakan fiskal pemerintah telah menetapkan Peraturan Menteri Keuangan No. 28/2020. Insentif ini digulirkan 
antara lain berupa pembebasan PPN, PPh (21) Impor, PPh (23), hingga PPh (21) dan berlaku sepanjang masa pajak April hingga September 2020 serta insentif bagi pelaku usaha dan UMKM sehingga mereka dapat berproduksi dan terhindar dari PHK.

Kebijakan yang dilakukan oleh Bank Indonesia, dan relaksasi yang diberikan oleh pemerintah belum memiliki pengaruh yang signifikan terhadap perekonomian di Indonesia, setidaknya bertahan dalam krisis ekonomi. Kebijakan moneter saat ini tidak bisa berdiri sendiri dalam mengatasi pandemi Covid 19. Oleh karena itu perlu stimulus fiskal dan kebijakan ekonomi serta kebijakan non-ekonomi lainnya. Sinergitas diantara keduanya saja tidak cukup dalam mengatasi pandemi ini jika ingin dirasakan langsung oleh masyarakat menengah kebawah.

Untuk menyentuh masyarakat menengah kebawah diperlukan peluang dan peran khusus bagi ISF dalam mengatasi pandemi Covid 19. ISF dalam hal ini yaitu bagaimana peran zakat, Wakaf, infaq, dan sedekah dapat disalurkan dengan jumlah target tertentu dan mempermudah akses penyalurannya untuk masyarakat menengah kebawah. Namun tetap tidak mengabaikan kebijakan Bank Indonesia dan pemerintah dalam melaksanakan relaksasi untuk ketahanan perekonomian. Oleh karena itu perlu integrasi dan sinergitas antara Bank Indonesia, Pemerintah, Lembaga Keuangan Syariah serta Islamic Scocial Finance untuk menyediakan jaminan sosial untuk pertahanan mata pencaharian masyarakat, memenuhi kebutuhan dasar/pokok, dan kemampuan daya beli masyarakat menengah kebawah.

Berdasarkan penelitian dari Universitas Institut Pertanian Bogor dan IRTIIsDB, potensi zakat di Indonesia mencapai Rp 217 Triliun. (Canggih, Fikriyah, \& Yasin, 2017). Jika potensi ini didapatkan oleh lembaga zakat sesuai dengan target, dana ini dapat secara signifikan membantu masyarakat menengah kebawah. Selain itu, potensi Wakaf di Indonesia sangatlah besar, dengan aset dalam bentuk tanah seluas $510 \mathrm{~km}^{2}$ (Fuadi, 2018). Potensi Wakaf juga mendukung untuk menyediakan kebutuhan dasar/pokok selama masa krisis. Sehingga pemulihan ekonomi dapat diatasi dengan baik. Wakaf tunai juga memiliki peran penting di Indonesia dalam mendukung pembelian peralatan medis.

Instrumen ISF secara keseluruhan dapat menjadi katalisator dalam menurunkan tingkat kemiskinan di Indonesia. Namun, instrumen yang terdapat didalam, tentu tidak dapat di lakukan secara singkat dan bersamaan. Sehingga, dengan peluang serta potensi yang dimiliki dari setiap instrumen kurang memberikan dampak terhadap masyarakat miskin. Oleh karena itu, perlu adanya optimalisasi serta pengaturan yang tepat dalam mengelola instrumen ISF 
seperti zakat dan wakaf dalam jangka waktu tertentu, dan inaq dan sedekah yang dapat diperoleh dalam jangka pendek. Berdasarkan latar belakang tersebut, penelitian ini dilakukan bertujuan untuk memberikan solusi berupa bagaimana cara melakukan optimalisasi peran ISF untuk meningkatkan ketahanan, serta pertumbuhan ekonomi di Indonesia ditengah pandemi Covid 19.

\section{METODE PENELITIAN}

Jenis penelitian ini adalah kualitatif deskriptif yang berupaya memahami berbagai macam konsep yang diperoleh dalam proses penelitian dengan menggunakan riset kepustakaan. Riset kepustakaan merupakan penelitian yang menggunakan jenis dan sumber data sekunder yang diperoleh dari hasil penelitian, artikel, dan buku-buku referensi yang membahas topik yang berkaitan dengan tema penelitian. (Iskandar, Possumah, \& Aqbar, 2020). Metode pegumpulan data melakukan wawancara terhadap salah satu representatif dari Badan Wakaf Indonesia (BWI) dan representatif dari Direktorat Jenderal Pengelolaan Pembiayaan dan Resiko, Kementerian Keuangan RI untuk mengetahui lebih lanjut pengoptimalisasian dana wakaf dalam meningkatkan kesejahteraan masyarakat dalam mengatasi pandemi Covid 19.

\section{HASIL PENELITIAN DAN PEMBAHASAN}

Optimalisasi Islamic Social Finance perlu dipetakan terlebih dahulu baik dari segi penerimaan dan penyaluran dana, dan pemetaan jangka waktu dalam mengimplementasikan dana tersebut baik kepada masyarakat menengah kebawah, maupun masyarakat yang terkena Covid 19. Pemetaan penggunaan dana zakat dan wakaf, lembaga keuangan Islam juga diperlukan dalam optimalisasi tersebut. Lembaga keuangan Islam harus bisa melakukan inegrasi keuangan sosial Islam, yaitu zakat dan wakaf kedalam bentuk operasional mereka untuk menyediakan jaminan sosial kepada masyarakat.

Zakat telah diatur didalam al-Qur'an bahwa terdapat delapan golongan yang berhak menerima zakat. Selain itu, dalam perspektif hukum tata negara, zakat dan pengelolaanya juga diatur didalam Undang-Undang No. 23 Tahun 2011. Hal demikian membuktikan bahwa Indonesia juga menempatkan zakat 
dalam hukum tata negara Indonesia, dimana negara turut campur dalam pengelolaan zakat.

Jika pemerintah atau negara memiliki tanggung jawab dalam mengelola zakat untuk masyarakat, maka zakat dengan optimal dapat diatur oleh negara guna mencapai dan mewujudkan kesejahteraan masyarakat karena pengelolaan zakat yang berdaya guna dan berhasil untuk mengentaskan kemiskinan.

Jika zakat diperuntukkan untuk masyarakat yang terkena Covid 19, tentu hal ini perlu dikaji lebih dalam. Berdasarkan kesepakatan Majelis Ulama Indonesia, zakat dapat diperuntukkan untuk kepentingan penanggulan Covid 19. Namun terdapat ketentuan yang harus dipenuhi, salah satunya adalah pendistribusian zakat harus secara langsung diberikan kepada penerima zakat yang termasuk dalam delapan golongan yang telah ditetapkan.

Dana zakat dapat berbentuk uang tunai, makanan pokok, hal-hal yang berhubungan dengan pengobatan, atau hal yang sangat dibutuhkan oleh penerima zakat. Bahkan pemanfaatan dana zakat dapat bersifat produktif, seperti untuk kepentingan masyarakat atau kebutuhan ekonomi masyarakat yang terkena Covid 19. Namun jika dana zakat dan dampaknya belum dapat memenuhi kebutuhan masyarakat yang fakir miskin yang terkena Covid 19, dapat diperoleh melalui infak, sedekah, dan sumbangan lainnya.

Peran zakat bukan satu-satunya instrumen yang bisa diharapkan dalam memenuhi kebutuhan masyarakat yang terkena Covid 19. Perlu diketahui bahwa dalam mengoptimalkan dana zakat ini tidaklah untuk jangka panjang. Karena sesungguhnya zakat tetap disalurkan kepada delapan asnaf yang lebih membutuhkan. Walaupun terdapat masyarakat terkena dampak Covid 19 yang termasuk dari delapan asnaf, jumlah tersebut tidaklah sebanyak masyarakat menengah keatas, karena virus pada awalanya lebih banyak menyerang orangorang yang umumnya bepergian antar luar negeri.

Menurut Yudhira (2020) pengoptimalan zakat dapat didesain untuk memenuhi kebutuhan jangka pendek dan panjang. Namun kebutuhan jangka pendek ini sangat dibutuhkan pada saat kondisi pandemi seperti melakukan program bantuan pangan, kesehatan, dan program konsumtif lainnya. Sedangkan untuk jangka panjang dapat dilakukan untuk program pendidikan dan ekonomi. Namun untuk jangka pendek, menurut Iskandar et al. (2020), zakat, infak, sedekah dapat mengatasi pandemi Covid 19 dengan cara pertama, penyaluran bantuan langsung secara tunai kepada masyarakat. Situasi seperti ini, menjadi peluang bagi masyarakat untuk saling membantu antar sesama, bukan hanya dilakukan oleh pemerintah. 
Demikian pula pendapat yang dikemukakan oleh Jureid (2020) zakat sangat berguna dalam jangka pendek terutama dalam bidang pangan, minimal dapat mengatasi kelaparan dan status gizi buruk yang seringkali melanda kalangan masyarakat miskin tertentu di daerah/pedesaan terpencil yang jauh dari keramaian kota dan berkumpulnya kelompok orang-orang kaya. Sehingga zakat dalam jangka pendek juga dapat mengatasi krisis pangan terutama di saatsaat terjadi bencana alam maupun disaat pandemi Covid 19.

Oleh karena itu, zakat cenderung digunakan untuk memenuhi kebutuhan jangka pendek. Dana zakat dapat digunakan untuk kebutuhan dasar seperti bahan pokok makanan, dan kebutuhan konsumtif lainnya, termasuk masalah kelangkaan APD, masker, kebutuhan desinfektan, pengobatan, kebutuhan relawan yang sedang bertugas, hingga kebutuhan pokok masyarakat terdampak.

Sementara instrumen wakaf, bisa juga digunakan dalam fasilitas sosial namun dalam pengaturan atau manajemen aset wafat, wakaf lebih diperuntukkan dalam periode jangka panjang. Pengelolaan wakaf produktif sebgaimana yang diteliti oleh Sirajuddin di masjid al-Markaz kota Makassar (sirajuddin:2018) Misalnya, wakif dalam mewakafkan asetnya harus menyertakan peruntukan wakaf. Sebagai contoh, wakif mewakafkan harta wakafnya untuk kesehatan seperti pembangunan rumah sakit. Maka, peran nazhir adalah melakukan upaya agar pembangunan rumah sakit terpenuhi. Selain pembangunan rumah sakit, nazhir juga perlu memikirkan biaya operasional terkait pembangunan tersebut. Oleh karena itu, wakaf lebih berdampak untuk keberlangsungan kehidupan masyarakat dalam jangka panjang.

Saat ini banyak juga lembaga keuangan syariah, salah satunya yaitu perbankan syariah bekerja sama dengan lembaga wakaf untuk mendirikan rumah sakit sederhana hanya untuk penanganan Covid 19. Kegiatan tersebut telah dilakukan oleh salah satu Lembaga keuangan Syariah yaitu BNI Syariah. BNI Syariah melakukan kerja sama dengan LAZ Dompet Dhuafa dengan mendirikan rumah sakit bernama RS Container Covid 19 yang terdiri dari 10 rangkaian dan memiliki fungsi sebagai ruang isolasi yang bersifat portable, ramah lingkungan, dengan proses pembuatan yang cepat dan tahan lama.

Namun karena penyaluran wakaf ini disalurkan tidak secara langsung seperti zakat, wakaf masih memiliki kendala. Namun untuk jangka panjang potensi wakaf ini sangat bermanfaat ditengah pandemi ini. Selain membangun rumah sakit, potensi tanah yang dimiliki lembaga wakaf juga dapat digunakan 
untuk lahan makam korban yang terkena Covid 19. Hal ini juga menjadi tantangan bagi nadzir dalam mengelola aseet wakaf yang ada, serta menghimpun dan menyalurkannya. Karena wakaf harus selalu diproduktifkan, hal ini juga menjadi sebuah nilai yang sangat bermanfaat dan dirasakan oleh masyarakat dengan cepat.

Selain wakaf yang menggunakan asset dalam bentuk lahan, dan pembangunan rumah sakit, untuk jangka yang lebih panjang lainnya dapat pula diterapkan Cash Waqf Linked Sukuk untuk pembangunan beberapa infrastruktur. Namun langkah ini dilakukan apabila pembangunan aset infrastruktur diatas tanah wakaf nadzir membutuhkan dana yang besar, oleh karena itu nadzir dapat menerbitkan sukuk. Menggunakan jasa kontraktor pembiayaan dilakukan bertahap sampai dengan aset infrastruktur selesai.

Namun bukan berarti Sukuk Wakaf tidak dapat dioptimalkan dengan baik. Menurut Iskandar et al. (2020) penguatan wakaf uang baik dengan skema wakaf tunai, wakaf produktif maupun waqf linked sukuk perlu ditingkatkan. Badan Wakaf Indonesia perlu bekerja sama dengan lembaga keuangan syariah untuk mempromosikan skema wakaf, yang pada akhirnya dapat digunakan untuk pembangunan berbagai infrastruktur berbasis wakaf seperti Rumah Sakit khusus korban Covid-19, APD wakaf, masker wakaf, poliklinik wakaf, Rumah Isolasi Wakaf, pengadaan ventilator wakaf, universitas wakaf dan lainnya.

Namun peneliti lain menyatakan bahwa akan ada asset wakaf lain yang dapat diwakafakan untuk kepentingan umat, salah satunya yaitu vaksin Covid 19. Jika vaksin secara resmi sudah dapat digunakan, diharapkan patennya dapat diwakafkan, sehingga dapat digunakan untuk seluruh masyarakat dunia. Oleh karena itu, penting untuk mengampanyekan pentingnya wakaf saat wabah pandemi Covid 19 kepada masyarakat termasuk kepada ilmuwan dan penemu atau peneliti vaksin (Sakni, 2013)

Selain pendapat dari beberapa penelitian sebelumnya, hasil wawancara yang telah dilakukan oleh penulis dalam melakukan diskusi terkait pengoptimalisasian dana wakaf, representatif dari Badan Wakaf Indonesia (BWI) dan representatif dari Direktorat Jenderal Pengelolaan Pembiayaan dan Resiko (DJPPR) Kementerian Keuangan RI memberikan informasi bahwa dana wakaf berupa Cash Waqf Linked Sukuk menggunakan metode Private Placement (SW001) dan Ritel (SWR001). Hasil diskonto dan imbal hasil yang diterima oleh wakif atau investor melalui metode Private Placement akan difokuskan untuk pengembangan retina dan glukoma centre Rumah Sakit Ahmad Wardi yang ada di Provinsi Banten serta alokasi untuk pelaksanaan operasi mata bagi dhuafa. Sedangkan SWR001 bagi hasil dialokasikan untuk program nazhir wakaf 
khususnya untuk bidang Kesehatan, Pendidikan, dan pemberdayaan ekonomi masyarakat sebagai mauquf alaih. Untuk kedepannya masyarakat yang terkena pandemic COVID-19, akan difokuskan dengan menerbitkan CWLS seri kedua yaitu SWR002. Namun hal demikian masih menjadi perbincangan dari berbagai pihak dari Badan Wakaf Indonesia

Selain zakat dan wakaf, bukan berarti infaq dan sedekah tidak dapat diupayakan dalam jangka pendek dan menengah. Indonesia sebagai negara yang cukup padat penduduk, diserta bonus demograsi yang tinggi, potensi sedekah dan infaq bisa diupayakan, tidak hanya integrasi antara sedekah dan infaq dengan perbankan syariah, namun juga bisa dilakukan oleh Baitul Maal wat Tamwil atau koperasi syariah, serta pelaku UMKM yang setidaknya dapat memberikan nilai sosial untuk penanganan Covid 19. Jika ISF ini dapat dilakukan secara optimal baik zakat, infaq, dan sedekah yang dapat dihimpun serta disalurkan secara langsung kepada masyarakat, dan wakaf menjadi instrumen untuk jangka panjang selama pandemi ini, dapat menekan peningkatan masyarakat yang terkena Covid 19. Jika sumber daya manusia bisa diatasi, maka pandemi ini diharapkan dapat teratasi dengan baik, sehingga perekonomian tetap berjalan dan terhindar dari krisis. Selain itu, jika Covid 19 sudah teratasi dan kegiatan perekonomian kembali berjalan normal dan optimalisasi ISF tetap dijalankan secara intens, dana zakat dapat terus disalurkan hingga angka kemiskinan semakin berkurang, dan diharapkan jumlah muzakki semakin meningkat. Selain itu, dana wakaf juga dapat membantu infrastruktur di Indonesia dengan cepat dan investasi tetap terus berjalan dengan menggunakan produk sukuk.

Literasi masyarakat terhadap keberadaan, potensi, dan manfaat dari Islamic Social Finance beserta pengetahuan masyarakat terhadap prinsip-prinsip serta nilai-nilai yang terkandung didalam ekonomi dan keuangan Islam sebenarnya sangat memiliki pengaruh yang sangat besar untuk mempertahankan perekonomian di Indonesia jika terkena krisis, seperti dampak yang dirasakan akibat Covid 19 ini. Oleh karena itu, optimalisasi ISF sangat penting untuk terus dilakukan baik ketika Indonesia sedang menghadapi krisis ekonomi atau tidak. 


\section{KESIMPULAN}

Pandemi Covid 19 memberikan dampak berupa krisis ekonomi secara global termasuk Indonesia. Namun krisis ekonomi ini dapat diatasi dengan cara mengoptimalkan instrumen yang berasal dari instrumen Islamic Social Finance untuk memberikan bantuan kepada masyarakat menengah kebawah dan masyarakat yang terkena Covid 19. Instrumen ISF dapat dioptimalkan dengan memplotkan masing-masing dari instrumen tersebut kedalam jangka pendek, menengah, dan panjang. Optimalisasi ISF yang ditawarkan oleh penulis yaitu pertama memberikan bantuan langsung secara tunai kepada masyarakat menengah kebawah yag berasak dari dana zakat, infak, dan sedekah; kedua meningkatkan produktivitas wakaf uang dengan memberdayakan Cash Waqf Linked Sukuk yang akan direncanakan oleh BWI untuk diterbitkan seri kedua yang dikhususkan untuk menangani masyarakat yang terkena dampak Covid 19. Jika optimalisasi ISF tersebut dapat dijalankan secara optimal, khususnya bantuan langsung dana zakat, infak, dan sedekah, dan begitu pula sinergitas antara pemerintah dan BWI dalam penerbitan seri kedua CWLS, maka diharapkan dapat membantu mempertahankan perekonomian sehingga terbentuk kembali percepatan dan pemulihan ekonomi di Indonesia 


\section{DAFTAR PUSTAKA}

Andiani, K., Hafidhuddin, D., Beik, I. S., \& Ali, K. M. (2018). Strategy of BAZNAS and Laku Pandai For Collecting and Distributing Zakah in Indonesia. Al-Iqtishad: Jurnal Ilmu Ekonomi Syariah(Vol 10, No 2: July 2018), 417-440. Retrieved from http://journal.uinjkt.ac.id/index.php/iqtishad/article/view/6943

Ascarya, A., HAkim, C. M., Rahmawati, S., \& Masrifah, A. R. (2018). Manajemen Risiko Pengelolaan Zakat. Indonesia: Pusat Kajian Strategis Badan Amil Zakat Nasional (BAZNAS)

Baga, L. M., Beik, I. S., \& Triyani, N. (2017). Manajemen Risiko pada Badan Amil Zakat Nasional (BAZNAS). AL-MUZARAAH(Vol 5, No 2 (2017)), 107-124. Retrieved from http://journal.ipb.ac.id/index.php/jalmuzaraah/article/view/19179

Beik, I. S., Ascarya, A., \& Asfarina, M. (2019). Re-Estimating the Zakat Potential in Indonesia Based on Classical and Contemporary Fiqh Approaches. Journal of Islamic Monetary Economics and Finance, 5(2). doi:10.21098/jimf.v5i2.1068

Beik, I. S., \& Ramadhan, M. M. (2013). Analisis Pengaruh Instrumen Moneter Syariah dan Konvensional Terhadap Penyaluran Dana ke Sektor Usaha Mikro Kecil dan Menengah (UMKM) di Indonesia. AL-MUZARAAH(Vol 1, No 2 (2013)), 175-190. Retrieved from http://journal.ipb.ac.id/index.php/jalmuzaraah/article/view/19749

Canggih, C., Fikriyah, K., \& Yasin, A. (2017). POTENSI DAN REALISASI DANA ZAKAT INDONESIA. al-Uqud : Journal of Islamic Economics, 1, 14. doi:10.26740/jie.v1n1.p14-26

Fuadi, N. F. Z. (2018). Wakaf Sebagai Instrumen Ekonomi Pembangunan Islam. Economica: Jurnal Ekonomi Islam, 9(1), 151-177.

Iskandar, A., Possumah, B. T., \& Aqbar, K. (2020). Peran Ekonomi dan Keuangan Sosial Islam saat Pandemi Covid-19. Jurnal Sosial \& Budaya Syar'i FSH UIN Syarif Hidayatullah Jakarta, 7(7), 625-638.

Ismal, R., Tahir, H. E., \& Mahfudz, A. A. (2020). Re: Redefining Islamic Finance in the Midst of COVID-19 Outbreak

Jureid, J. (2020). Ekonomi Syariah Sebagai Alternatif Kesejahteraan Ekonomi Masyarakat Pada Era COVID-19. JEpa, 5(2), 224-236.

Mussry, J., Ridwansyah, A., Meiza, R., \& Laksmana, D. U. (2020). Re: Coronavirus vs UMKM 
Nasional, P. K. S. B. A. Z. (2020a). Indeks Zakat Nasional 2.0. Indonesia: Pusat Kajian Strategis Badan Amil Zakat Nasional (Puskas BAZNAS)

Nasional, P. K. S. B. A. Z. (2020b). Indeks Zakat Nasional dan Kaji Dampak Lembaga Amil Zakat 2019. Indonesia: Pusat Kajian Strategis Badan Amil Zakat Nasional

Naufal, A., Hafidhuddin, D., \& Beik, I. S. (2018). Strategi Pengelolaan Zakat dalam Menanggulangi Pemurtadan di Kabupaten Gunungkidul Yogyakarta. Kasaba(Vol 11, No 2 (2018)), 203-216. Retrieved from http://ejournal.uikabogor.ac.id/index.php/Kasaba/article/view/2467

Nisa, F., Bayuni, E. M., \& Eprianti, N. (2019). Efektivitas Pelayanan Penghimpunan Dana Wakaf terhadap Kepuasan Donatur di Sinergi Foundation Menggunakan Metode DEA. Prosiding Hukum Ekonomi Syariah, 641-648.

Rohim, A. N., Tanjung, H., \& Beik, I. S. (2018). Analisis Fiqh Pola Penyaluran Zakat. Kasaba(Vol 11, No 2 (2018)), 217-236. Retrieved from http://ejournal.uikabogor.ac.id/index.php/Kasaba/article/view/2468

Sakni, A. S. (2013). Konsep Ekonomi Islam dalam Mengentaskan Kesenjangan Sosial: Studi atas Wacana Filantropi Islam dalam Syari'at Wakaf. Jurnal Ilmu Agama: Mengkaji Doktrin, Pemikiran, dan Fenomena Agama, 14(1), 151-166.

Sirajuddin, S. S. (2018). Pemberdayaan Tanah Wakaf Sebagai Potensi Ekonomi Umat Di Masjid Al-Markaz Al-Islami Makassar. Laa Maisyir: Jurnal Ekonomi Islam, 5(1).

Sukmana, R., Indrawan, I. W., \& Ajija, S. R. (2020). Impacts of the Covid-19 Outbreak on Islamic Finance in the OIC Countries. Indonesia: National Committee for Islamic Economy and Finance

Yudhira, A. (2020). Analisis Efektivitas Penyaluran Dana Zakat, Infak dan sedekah Pada Yayasan Rumah zakat. VALUE, 1(1), 1-15. 